\title{
Globalization, Power and Survival: an Anthropological Perspective
}

\author{
Marc Abélès \\ Ecole des Hautes Etudes en Sciences Sociales, Paris \\ LAIOS (Laboratoire d'anthropologie des instititutions et des organizations sociales) \\ IIAC (Institut interdisciplinaire d'anthropologie du contemporain) EHESS/CNRS
}

Article paru dans Anthropological Quarterly, vol 79, 3, Summer 2006

We are accustomed to emphasizing the economic aspect of globalization and it is true that globalization corresponds to a displacement from a primarily industry-based economy to one where working on concepts plays a major role and where trade growth is tied in with financial deregulation and the new approaches this implies in terms of the circulation of capital. It is possible, though, that we have given insufficient weight to the fact that globalization is first and foremost a cultural phenomenon.

We should not see the violence of globalization purely and simply as a process of domination - like some new form of colonialism. The power of its impact is all the greater for the fact that it consists of a profound change in our awareness of time and space. "Globalization as a concept refers both to the compression of the world and the intensification of our consciousness of the world as a whole" (Robertson 1992:8). For Westerners, this notion of a self-contained world expresses itself in a strong feeling of insecurity. It only needs a sector of the economy, for example, to show signs of weakness, for the possibility of relocations to emerge. In the confrontations between staff and bosses that have always punctuated economic life, the outcome used to be that of a solution that took into account local social and economic conditions. Now, we "think global" - meaning that relocation appears from the outset to be a pertinent alternative. In the face of this prospect, workers are caught in a very simple dilemma: either they accept the "sacrifices" or the company will quite simply disappear. Beyond this recurrent blackmail, what weakens people is the sense of the extraordinary "nearness" of other lands - which are easily identifiable, whether it be a country in Eastern Europe or Asia. 
There is sense of temporal "nearness" too, in that in a few weeks or even days one can create a similar company on the other side of the world.

In practice, the compression of time and space can be perceived as a threat, not only because it accentuates the pressure of the invisible hand of the omnipotent market system, but also inasmuch as it makes possible a violent intrusion of alterity into our world. This was the case on September 11, 2001, when a place that represented the quintessence of the market was brutally attacked by a group that incarnated radical exteriority. We realized how easy it was for people we tended to think of as being on the other side of the world to reach the heart of the system by turning peaceful technologies into fatal weapons.

The awareness of globalization, therefore, is more than just the apperception of an ever closer interdependence of economies. It is equally, if not more, a matter of the citizens of the developed countries internalizing a simple, disturbing reality: that they will never again be "safe" from a threatening "elsewhere", hitherto considered marginal and today able to organize itself in a most "modern" manner and burst in. The whole "modernity" position, though, was based on the idea of there being an irreducible difference between all that represents civilization and fits into the scheme of progress and these Others who, while being part of humanity, were nonetheless doomed to the inertia of beings without history. We are part of the same planet, our destinies appear to us to be increasingly intertwined. There too, the evaluation can be interpreted optimistically: the fact that the compressing effect of globalization breaks down certain barriers between societies, overturns prejudices and obliges us to mix is cause for rejoicing. The concepts of cross-fertilization and hybridization have been invoked to describe the possibility finally at hand of a meeting between cultures so long separated and so long isolated by prevailing ideologies. The opposite of this ecumenical vision is an interpretation that highlights the virulence of the tensions generated by another huge present-day reality: that the other side of world unity is that resources and riches have to be shared.

Twenty or so years ago, we wanted to do away with all form of segregation. We can all recall the great commemoration of 1989 and the multicultural parade organized by Jean-Paul Goude. This was the great reconciliation - the melting pot. It was under the aegis of the Whites, of course. The Other was present, but we had the upper hand and had 
summoned him to help us hold our own history up to the mirror of this commemoration. We all knew that as soon as the celebrations were over everyone would go back to his place, with us in the center and them on the periphery, according to an order which, at the time, seemed inviolable. At that period, an open world meant that distance was not about to disappear. Even those who criticized the new incarnations of colonialism and western domination placed opposition between center and periphery at the heart of their ideas and spoke of conditions for a better future.

What now seems problematic is the wideranging impact of this model, for at least two reasons. The first is to do with the pressure exerted by poverty and alterity. On one hand, we're no longer dealing with a "Third World" group passively suffering the consequences of the capitalist dynamic, but with an increasingly diverse group of societies, including countries entering into world economic competition and voraciously claiming their share of market. The second reason for the weakening of the center/periphery paradigm relates to the displacement going on with these categories. It is clear today that the periphery has become an integral part of the center. The struggles of illegal immigrants are eloquent proof of this: exclusion is at the heart of our societies.

In this context, we can see the main problem our societies have to confront more clearly. Although many questions may arise concerning their future, the question that has to be addressed today seems to me to be the political question. What is at issue is "acting together", to use a term of Hannah Arendt (1958), and the instituting of means by which acting together can appropriately reflect society's demands. What expression can citizens' questionings find, and in what framework? What does governing mean, in this context of global compression? Why, for whom, and how? And, last but not least, is there a place today for politics? If we look back at the previous period, we can see that it was dominated by the social question. The seriousness of the social question ended up by first considerably strengthening the political dimension's impact and broadening its legitimate field of intervention - traditionally limited to the domain of the police, diplomacy and defense - and secondly by shaping the demand for politics in our societies. And yet what do we see, when the end of the $20^{\text {th }}$ century is simultaneously marked by the collapse of communism, the financialization of the economy and its worldwide deregulation? The parameters of global trade are progressively coming to dictate their law, and the state 
appears increasingly eclipsed in terms of determining factors over which it no longer has any real leverage. The political dimension seems helpless, lacking any ability to forecast. It is as though its role were reduced to that of accompanying, as far as is possible, the general disillusionment and to absorbing, at least verbally, the jolts of the global economy.

In these conditions, it is not surprising that belief in the impact of politics has given way to skepticism. This is all the more the case because everyone senses that the changes in the global economy are not such as will strengthen the nation-state form, which had, in the last century, a structuring role as far as politics was concerned. The decline in the state's sovereignty over the economy is related to the capacity of world business to operate, to a great extent, within the framework of market-governed regulation that partially escapes state influence. Consequently, governments no longer control markets in fact, even the opposite is happening (Strange 1996). Indeed, economic policies depend, in large part, on an economic and financial situation that is hard to control at national level. In addition, post-bipolar evolution is leading to a destruction of the sacred aura surrounding sovereignties. At the same time, the rising power of "global cities" - those metropolises of transnational capitalism that "concentrate a disproportionate share of corporate power and are one of the key sites for its overvalorization", but which "also concentrate a disproportionate share of the disadvantaged and are one of the key sites for their devalorization" (Sassen 1998) - also contributes to a limiting of the impact of traditional state systems. Not only weakened by the triumph of the market economy, state sovereignty is also challenged by the forming of large groupings integrating entire regions of the globe: the European Union, MERCOSUR and NAFTA, and ASEAN and APEC in Asia. The state is also overwhelmed by the complexity of the challenges and caught between the demands of the global and the tenacious realities of the local.

Does not the interdependence between economies and the need for a change of scale in the management of financial and human flows eventually have the effect of weakening the notion - so dear to political scientists - of sovereignty? Of course, borders and demarcations still make it possible to distinguish between constituent nation-states, in all their multiplicity. By the same token, as the current conflicts on the planet eloquently testify, the claim to the full exercise of sovereignty remains omnipresent just about 
everywhere. But the politics of the great powers, which reached its peak with the cold war and was expressed in a veritable world order focused around the east-west divide, is giving way to a more complex reality, marked by a double process. On one hand, there is the apparent hegemony of the superpower, the United States, and on the other, a sense of the weakness of this organized power in the face of violence - of which September 11 was the most spectacular manifestation.

One of the most visible effects of globalization is that it creates a widening of inequalities, notably between the north and the south, and a disintegration of traditional social and cultural fabrics. In this context, the appearance of new forms of violence, based on self-sacrifice, which may take more or less sophisticated forms, has changed the traditional order of war studies. In the face of the violence of the state, it is the action of deterritorialized, mobile and dispersed networks that will henceforth tend to prevail. This may destabilize long-reigning strategies that put a type of centralized organization in the foreground and depended, to a great extent, on an efficient armaments industry.

In other words, the existence of a globalized stage where the flow of terrorist movements is as intense as the flow of information (the latter multiplying the former) profoundly transforms our perception of power - based as it is on the primacy of the nation-state. Perhaps it is time to realize the obsolete nature of a system of government that proved itself throughout the last century. The nation-state, based on isomorphism between people, territory and legitimate sovereignty is profoundly called into question by globalization. The proliferation of deterritorialized groups and the "diasporic diversity" that we see almost everywhere have the effect of creating new, translocal solidarities. We see identity constructions emerging that go beyond the national framework. In their own way, state policies play a part in fostering this situation by giving rise to migratory movements. The anthropologist Arjun Appadurai (1996) has underlined the highly heterogeneous nature of such movements. Refugees, workers, specialists from companies or international organizations and tourists are very different types of migrant. But, in every case, widespread movement is at the root of new, subjective referents that are making forms of identification linked to territory and the state increasingly anachronistic. Refugees, tourists, students, workers and migrants all form, in their way, a delocalized "transnation". 
In these conditions - and this is the extreme consequence to which Appadurai's observations lead us - it is clear that we have now entered the postnational era. The new forms of organization playing a front-ranking political role, in areas as diverse as the environment, the economy and humanitarian aid, show a fluidity and flexibility that contrast with the rigid structures of traditional state apparatuses. The non-governmental organizations (NGOs) being developed all around the world, often in connection with crisis situations, are highly representative of a new political model more directly anchored in civil society, that blithely transcends national borders. The transnationality that increasingly characterizes the globalized world requires new networks of solidarity and more labile modes of action. In fact, we can see postnational sovereignties already emerging - and even the idea of patriotism still has some value, inasmuch as we are dealing with a "mobile, plural and contextual" patriotism.

In fact, Appadurai concurs with the views of political scientist James Rosenau (1992), for whom the state no longer plays a central role in a world where "governance without government" prevails. This governance involves the intervention not only of the political dimension but also that of other players from civil society. In a world increasingly threatened by various kinds of turbulence, including terrorism, the proliferation of nuclear weapons and mafia-orchestrated trafficking, the need for transnational governance is gradually becoming obvious. The increasing power of organizations aiming to provide types of regulation on a larger scale is the symptom of an evolution that leads Bertrand Badie (1999) to clearly raise the question of a "world without sovereignty".

Those who see in the erosion of the state one of the highlights of the new international order are quick to affirm that we have entered the "glocal" era. Are we moving towards an extended world governance, like the implementing of common rules by an authority whose legitimacy is recognized on a planetary scale? Analysts highlight the new power acquired by supra-national bodies and the appearance of "non governmental" organizations, of sometimes-unclear status, which have nonetheless managed to be in the news in contexts where the diplomacy of states was hitherto the sole authority.

As I see it, the central point is this political displacement, which may or may not result in a reorganization of the institutional arena but which is by no means merely confined to 
the institutional arena. We must try to identify the "stuff" of this displacement, avoiding falling back on old moralizing or psychologizing ideas about political disillusionment.

Alongside the European project, the end of the $20^{\text {th }}$ century saw a growth in the strength of a whole set of transnational organizations with no explicit governmental aims, such as the World Bank, the IMF, and the WTO. In the context of a fluid society, it appears that these organizations, whose players remain anonymous for the general public, have taken a pre-eminent place. Today they seem omnipresent and impenetrable, enjoying visibility as a result of their effects. They escape the usual issue of representation, and it is revealing that they should be seen to such a degree as distilling power and authority. In just a few years, these organizations have become a target for all those who denounce the social and cultural ravages of the new paradigm. It is no accident that the meetings of the WTO have sparked off major demonstrations. The 1999 Seattle demonstrations unquestionably marked a turning point, with the rise in power of a vast altermondialist movement. When we look back over the last 10 years, we are struck by the remarkable conjunction of two phenomena. On one hand a certain number of the key elements of governance, in areas as diverse as the economy, the environment and the rights of man, have partly been taken charge of by these transational organizations and, on the other hand, a battlefront has developed that designates these new powers as the main target.

There is a dual displacement, then, in both governmentality and resistance. In reality, what characterizes the present is the emergence of a new political stage set, with its own specific figures and challenges, whose true place can be gauged when confrontations occur, like those that marked the WTO meetings and the G7 summits. Davos and Porto Alegre have become the symbols of the political displacement and of the way in which traditional intra-national antagonisms have not just acquired a new dimension but, for better or worse, reflect a political vision of the world that will never again be that which prevailed for so long within parties and other organizations that have been, until now, at the heart of the power balance in their respective countries.

In other words, when we talk of the political displacement, analysis in terms of institutions and players can only imperfectly account for what has been rumbling below the surface for some fifteen years. We can measure the limits of this approach through the 
debate it gives rise to, which concerns above all the issue of knowing whether state sovereignty is or is not threatened by globalization. Here, we reason exclusively in reference to power balances, at the risk of losing sight of the essential: what is really at stake in the dynamic that can no longer be ignored, in which both the citizens and their leaders are involved. Must we restrict ourselves within thinking that focuses entirely on the powers of states and those of international structures?

Legitimate though it is, the interest in this question risks masking a deeper phenomenon. The reorganization of the "powers that be" and the increasing power of the transnational on a planetary scale is only the tip of the iceberg. Deep down, what is at issue is the very meaning we give today to the business of politics, and our perception of the political dimension, which is in the process of radically changing. The political displacement is determined by a global redefining of the meaning and aims of political action. This redefining does not only have a cognitive dimension, it shows up in ways of acting and in organizational and institutional constructions - and also in the position of issues that will be a focus for public debate and in the construction of the type of place where this debate will happen. This theory is heavy with consequences: it effectively implies that the emergence of a new, transnational stage is the effect rather than the cause of a profound transformation of our relationship to politics. This means that, in research, the institutional process must give way to an investigation of our perception of politics. It is here that the displacement, whose most visible effects we have spotted, is really happening.

In these conditions, it is best to take a step back regarding ideas as omnipresent as those of state and sovereignty. Hastily associating modernity and the preeminence of the state has the danger of making it impossible to understand a change that actually leads to a displacement of the "political place". While political anthropology has contributed to dereifying the political dimension, by showing the degree to which a focus on the form of state control had ultimately obscured the real diversity of the figures of power, Foucault, for his part, has underlined the need to ask the question "how" and look at the exercising of power. Reflecting on power as an action - as a "way of acting on actions" (2001:1056) - was also to challenge the traditional instruments of the political theories that "had recourse to ways of thinking about power that were based on either legal 
models (what legitimizes power?) or institutional models (what is the state?." (2001:1042) This meant we had to remove the legal and institutional biases from our approach to politics.

A focal issue in this new perspective is that of the governing of men. Here we come to a theme dear to Foucault: that of the art of governing, or in other words the practices by which we manage to "structure the possible field of action of others" (2001:1056). One of the difficulties encountered by any anthropology of power comes from the permanent overlap that exists between "the art of governing" together - of concrete procedures that define the field of power balances - and a theory of sovereignty that claims both to establish the legitimacy of these procedures and to extend their meaning, even if it means postulating a transcending horizon - a "herafter" of power.

As far as politics in "near" societies is concerned, the entanglement of power and sovereignty theories is so strong that only an effort of "defamiliarization" can make it possible to highlight the displacement - as Foucault tried to do by making history play the role of an operator making it possible to both take a distant view of contemporary power and bring its constituent elements to light. In the 17th and 18th centuries, a new mechanism of power was invented that applied to people rather than land. Yet the traditional theory of sovereignty is linked to a power exercised above all on the land and its products and not on the bodies of subjugated individuals. Power aims, above all, to seize goods and wealth - not working hours: "This theory makes it possible for power to be based on and around the physical existence of the sovereign and not at all on and around continuous and permanent surveillance systems.” (2001:186)

Foucault shows how what he calls a "power mechanism" applying to bodies rather than land was put in place at the same period. The aim of this power was to "obtain work and time from bodies rather than goods and wealth" (2001:186). It was to be the key instrument of the development of industrial capitalism. This disciplinary power does not emerge from the traditional theory of sovereignty. The "disciplines" standpoint is not that of the law; it refers to nature and aims to standardize behavior. Medicine, medicalization and "human sciences" all contribute to this structure.

Beyond bringing to light the emergence of disciplinary techniques centered on the individual and his body, Foucault also shows how a new technology, dealing with men in 
their multiplicity - the population - was put in place at the end of the $18^{\text {th }}$ century. This technology, which he calls biopolitics, deals with the population as both a scientific and political issue. The interest taken in demography, the development of public hygiene, the institutions of assistance and insurance and the taking into account of the relationship between man and the environment define a new configuration where the disciplinary dimension fades in favor of a project that aims to prolong life and regulate biological mechanisms. With the rise in the power of capitalism, these disciplinary work technologies acquired less direct procedures that allowed power to be taken over men as a group of living beings. Man was no longer just subjugated in his individual singularity, he was also controlled as a specimen of a population of living beings: the population as an undivided entity was the new subject of biopolitical sovereignty.

While disciplinary techniques were especially associated with man seen in his corporal individuality - man as a body - biopolitical techniques integrate the multiplicity of men into a global whole by focusing on man as a species. Unlike the disciplinary approach, which stuck to "anatomo-politics", biopolitics implies authority taking control of the processes affecting life, from birth to death (sickness, old-age, handicap, environmental factors, etc.) - which, although absolutely random at an individual level, have, as a collective phenomenon, decisive economic and political effects. The birth of police science and the premises of the politics of public health have progressively placed biological or natural life amongst the technical management preoccupations, calculations and forecasts of the state. The conformity of the lifestyle and customs of its political subjects preoccupies the state far less than their birth, their registration in the political registers of nationality and the demography of their biological life.

At a biopolitical level, the individual is no longer targeted, but is considered by the biopolitical norm as a specimen of a population whose movements must be regulated, both internal and external - diminution, growth, geographical movement. In contrast to traditional sovereignty, characterized by the power to make die or let live, power is now defined by its capacity to make live or let die. Far from being in contradiction with this redefinition of power oriented towards life, state racism, having been responsible or millions of deaths, has proved itself actively involved in the issue of the "biological strengthening" (Foucault 1997:230) of a population. 
Among the lines of research followed by the author of La volonte de savoir is one we cannot neglect. One could see Foucault work on biopower as a sort of genealogy of the modern welfare state, whose particular rationality he tries to bring out. But throughout the investigation, the trail he follows is that of the way in which the "delicate reconciliation of political power exercised over civil subjects and pastoral power exercised over living individuals" (2001:963) has been implemented. Two traditions are involved and, beyond that, two sets of perceptions that never align with each other. On one hand is a perception of power or the relationship of government to governed seen in terms of the metaphor of the shepherd leading his flock. The pastoral theme is prevalent in ancient oriental societies. The other tradition, illustrated notably by Plato in The Statesman, sees in the art of governing the capacity to achieve the unity of the city - to "weave the most magnificent of all fabrics". The welfare state could be said to constitute an unusual moment in history, in that it managed to bring the two perceptions together in a single, cohesive whole - the state as "centralized and centralizing power", orientated towards the citizen, and "pastorship" as the "individualizing power" (2001:955), aimed at individuals.

We might well wonder if this harmony between pastoral power and the centralizing state hasn't disappeared today. It is as if, now, a dislocation were taking place in our perception and experience of the political dimension between what comes under citizen/individual and what relates to biopolitical subject. Let us not be mistaken about the use made here of the Foucauldian categories. I am aware that these were developed to account for the complex relationship between the state and the individual - by avoiding reducing power merely to its repressive dimension, as ideological discussions of totalitarianism sometimes do. Foucault never tires of repeating that highlighting the negative aspect of power and interpreting it unequivocally in terms of law and proscription leads up a blind alley, by merely portraying a face-off with no solution, between an all-powerful sovereign and a subject forced into voluntary servitude. The philosopher's entire efforts have centered on bringing out the importance of this relationship as a producer of modes of subjectivation that condition the existence and lifestyle of individuals. At the same time - and this may be one of the limitations of the Foucauldian approach - the issue of subjects' relationship with politics is only tackled 
from the point of view of the relationship between the state and individuals, under the concepts of power and resistance.

The prevalence of the state viewpoint in Foucault's approach should not, however, make us lose sight of the way in which, in achieving a separation of the issues of power and sovereignty, Foucault reintroduces ambivalence in political theory. Taking seriously the biopolitical dimension radically complicates the traditional vision of the res publica as a harmonious space where subjects engage in political dialogue having laid aside all attributes other than those of citizenship. While the author of Surveiller et punir does not explain this ambivalence, it is a constant nagging presence in his work. And by taking this ambivalence seriously we can better understand what is being played out today in the shape of the "political displacement". We have to look at the current disjunction between the biopolitical point of view and the citizen/individual point of view in its own dynamic. In fact, we can actually speak of a real switch-over, with the rise in power of political representation that puts the preoccupations of life and survival at the heart of political action, while the issue of the city and the relationship of the individual to sovereignty is relegated to the background. The displacement of issues can find another expression, in a simple question that we all ask: that of "what will our world consist of tomorrow?" It is this fundamental anxiety that not only alters our relationship to politics but also determines the space that can be allocated to this activity and the new places in which it is best exercised.

This is demonstrated by a certain number of phenomena that merit analysis from this perspective and which lead us to reflect on what makes up the everyday political reality of each one of us. Bergson spoke of the "immediate data of consciousness". We might paraphrase his expression by considering the "immediate data of politics" - in other words, those preoccupations that are now inseparable from our way of being in society. They all have in common the fact that that they throw us beyond the well-defined world of a national community whose history and relative homogeneity within its own borders guarantee permanence and tranquility. It is as though something has become unbalanced, that everyone in his or her own way is trying to comprehend by attributing this situation either to an event (September 11) or a type of causality we cannot control (climate change). A sense of powerlessness has become the backdrop for political action. It is as 
though the citizen's capacity for initiative were going through a more or less explicit reassertion of this admission of powerlessness, tied to the awareness of a radical reappraisal of our terms of belonging. The other side of this position is a projection towards a vaguer collective interest relating more to survival (survivance) than to the art of "harmonious living together" (convivance).

In fact, the world of harmonious living together (convivance) corresponds to a political tradition maintained in the national state framework and centered, above all, on synchronic harmony between beings who operate in the reassuring world of the city, or at least orient their actions according to this perspective, even when they are tearing each other apart in endless conflicts. Harmonious living together (convivance) does not involve the idea of a world at peace. In fact, it has given rise to sharply contrasting political theories, some emphasizing the role of violence and domination as the regulator of living together, while others base political unity on the determining of a common enemy. There certainly exists a more peaceful vision of harmonious living together (convivance), such as that developed by Habermas in his theory of communicative action, which gives a leading role to argumentative procedures - essential instruments, according to this philosopher, in the resolution of conflicts. But we can equally share the point of view of Hobbes, for whom political society derives directly from the destructive impulse inherent in every human being, which leads him into a dog-eat-dog relationship with his fellows. What interests us here is that political theorists have in mind a state of the world that presupposes the actual or potential existence of stable communities. They suggest that the individual's main aim is to preserve this type of community - of which the nation-state represents the most evolved integrative form. In other words, this is saying we are dealing with a type of political action whose "sufficient reason", as Leibnitz would have said, is achieving the stable collective.

Let us now imagine a different, even very different, state of affairs, where harmonious living together (convivance) no longer represents the principal aim of societal beings, and that they have, in fact, established another priority. Let's suppose, for example, that the theories we habitually refer to do not take into account the possibility of such a change of objective. We are disturbed, thrown off balance and saddened in the face of a state of affairs no one seems to have seen coming. But perhaps, we might object, this situation 
only appears to be new and we only need refine the models we already have to grasp its meaning. Such a solution would have the advantage of being less intellectually costly. It would at any rate correspond to the dominant theories of contemporary society. In fact, we are always looking at the discrepancies between these theories every time we tackle the very specific issue of insecurity - which is also localized, since we take the case of France as our starting point. Following this thread, we will find ourselves led into taking account of a much more far-reaching set of preoccupations that shape the entire relationship of the individual to politics.

The survival (survivance) issue plainly stands out in even greater relief for the fact that it corresponds to the weakening of the rock that has represented, for western societies, the formidable power of a state that is both national and protective. It is hardly surprising that individuals are directly affected by the loss of bearings implicit in such a collapse. In terms of social relationships, there will be a weakening of the collective bond forged in an institutional context whose fragilities are increasingly apparent. In terms of territory, demarcations hitherto relevant to living as a community and feeling part of one are melting and opening out onto a world as vast as it is blurred. To a great extent, the state, whatever the powers of the time did with it, had been invested with a network of beliefs and had, in sometimes tense conditions, taken over from religion - accounting for considerable symbolic investment (Agulhon 1989). The state represented not only a power of assistance, but also an "insurance" in terms of the future. What was disappearing at the end of the $20^{\text {th }}$ century was "this capacity to control the future" that had characterized the triumph of the welfare state during the years of economic growth following WW2, with hope for social progress as a correlate (Castel 2003). In the new configuration, this very system - that guaranteed the possibility of some consistency between "my present life" and "my future" - is becoming fuzzy. The problem is not one of management of the city, since the state is still functional in this respect. In other words, the subject of harmonious living together (convivance) is not relevant here and political theory is off balance in the face of a questioning focused primarily on subjects' relationship to the future. This is what the survival (survivance) issue bluntly raises, for there is now an element of uncertainty lodged in people's minds, coexisting tensely with 
the hope - created by technical and scientific advances - that it is possible to live better and longer.

The fact that the future looks like being a permanent, pertinent question, in a situation in which uncertainty factors are multiplying, is shaping our relationship to politics. I purposely use the idea of "survival" (survivance), in contrast with the analysis of survival (survie) - which has been given by Elias Canetti. Survival (survie) implies a fundamental antagonism between I and others. It is associated with power. On the battlefield, the more corpses of my friends and enemies are piled up around me, the stronger I feel. "The survival moment is the moment of power." (1962:241) The quintessence of survival (survie) is invulnerability. Death is behind us and no longer presents a threat, because we've defeated it. The issue of "survival" (survivance) reaches into a different temporal realm: we are not in the future, in the pleasure of the present felt by those who have overcome the gravest peril, expressed, according to Canetti, in a feeling of strength, of sovereignty and "a feeling of election" (1962:242). Here, on the other hand, everything relates back to insecurity, to the uncertainty of a possibly futureless tomorrow. With the damage caused by progress, thanks to insecurity and all its many forms, the future is transformed into a threat. How can we banish uncertainty? This is how the vague sense creeps in that no authority can actually deal with the sort of heavy shadow that looms over the present. Ulrich Beck describes what he designates the "second modernity" by this omnipresent uncertainty characteristic of "the global risk society". According to him, one of scientific development's most spectacular effects is to have vastly increased insecurity.

Biotechnological discoveries, far from calming fears, actually generate new anxieties hence the implementation of the "precautionary principle", which, for the political dimension, creates a new demand. It is now confronted by situations where it is required to anticipate and choose between different possible outcomes, looking at things from a worst-case scenario point of view.

In our democracies, where harmonious living together (convivance) has been an issue for several centuries, we have few instruments for reflecting on politics from the point of view of survival (survivance). 
What gives the NGO phenomenon its rather unusual character is that the activity of these organizations is focused on the economy of survival. Consequently, their urgencyimbued stance also fits in with an outlook of a future made uncertain by the threats engendered by the merchandization of the universe. The economy of survival carries within it the issue of sustainability. We see this clearly in the area of the environment, where catastrophes regularly give us cause to evoke the responsibility of a productivist development model centered on profit. The reactions of the populations of the developed countries to the great recent natural disasters are entirely symptomatic of the response elicited by crisis situations. We saw this at the time of the Tsunami - the tidal wave that, in December 2003, ravaged the coasts of a dozen southern Asian countries, leaving hundreds of thousands dead in its wake. We witnessed at this time an immense outpouring of collective generosity. The intensity of the solidarity can be explained by the timing (the announcement of the catastrophe in the middle of the holiday period, and the feeling of living in peace and prosperity at a moment when others were abruptly stricken) and by the fact that westerners had been more directly affected than had been the case during other seisms (holidaymakers on the Asiatic coast had not been spared).

Following the Tsunami, the mobilized NGOs appealed to private individuals, and here we see the impact of the economy of survival on individual behavior. The sheer scale of private donations shows it, particularly in Europe and the U.S. Even in a country like France, not usually noted for great charitable enthusiasm, individual rallying to the cause took an impressive turn, in the shape of a veritable "humanitarian Telethon". In one day, SMS donations reached over $€ 1$ million. Looking back, what is striking about the breakdown of the donations is the fact that the amount of private donations almost reached that of the effort agreed by the state. This was an unprecedented phenomenon, suggesting that the citizens wanted to express their commitment to the humanitarian effort directly. In this context, the use of technologies like Internet or SMS - which make it possible to be directly involved in a global-level action while being confined to a local site - contributes to changing the traditional order of things. The individual can now step to the fore as a global player.

In the face of the traditional mediations embodied by national governments, a planetary donors action group is forming. This is embodied in the media in two ways: we 
are shown people admirably involving themselves in order to come to the aid of victims. If we mean by politics the relationship that unites the individual with the group and the way in which the individual sees his integration into the city, we may well wonder if, on this level, there is not some profound change going on. In fact, our behaviors and the priorities that determine group action, plus the very fact that rallying of this nature and extent is possible in the face of this type of catastrophe, reflects both anxiety and new awareness. The new awareness is that the world we live in may disappear and that, eventually, the survival of the species is threatened. This reaction is absolutely consistent with the response elicited by the theme of sustainability. Without doubt, it expresses an even more profound "anthropological anxiety". The NGO phenomenon fits into this perception of a world marked by this threat and risk, where tragic events regularly remind humans of the precarious nature of their situation.

Certainly, today, organizations whose purpose is the economy of survival represent a powerful opposition force. The NGOs and the social movements have clearly never put up so much of a fight. They brought about the failure of the Mulilateral Agreement on Investment (MAI) - proposed by the OECD and largely favorable to entrepreneurism. They caused powerful genetic engineering companies in Europe to back off. We saw them play a leading role in the failure of the WTO negotiations in Cancun, where cotton producers of the developing countries rejected an agreement the U.S. wanted to impose on them. Gradually, political and economic powers have understood that they now really have to "reckon with" what is referred to under the controversial label of "civil society". On the NGO side, the question on the table is now whether to follow a strategy of automatic protest by favoring the tribuneship function or contribute to global governance by gaining acceptance for their views - which would involve use of both pressure and negotiation. An organization like Oxfam, which played a leading role in the failure of the Cancun conference, still claims to support the existence of the WTO, inasmuch as the latter means the implementation of regulation at a global level. The aim of these NGOs is not to reject the market economy, but rather to establish a "connection" between the problems of people in the field and the global governance viewpoint and bring out the effects of this within that market economy. This is how to get concrete results and allow the southern countries to have access to worldwide trade, in giving them a chance to 
improve their economic situation. What is new in terms of the charitable purpose of the NGOs is not only their ability to connect the humanitarian problem to that of development but also the way in which they have been able to link the issue of development to that of global governance, on the basis of interpellations resulting from poverty and concerning the distribution of wealth. It is not a matter of accepting the rules of the game as laid down by the WTO as an intangible fact, but of publicizing, in this framework, the main question, which can be summed up as: Why it is that regulating international trade tends to favor preferential systems that benefit the rich countries?

\section{Towards global politics}

We can nonetheless still discern a divide between movements which, like ATTAC, challenge the WTO for being representative of neo-liberal hegemony, and the NGOs, who want to participate in the regulating process. Radical altermondialists see themselves as making no concessions to the world system - which they intend to bring down. They opt for a "breaking-off" and champion this at the major international forums. This explains the fracture existing at the heart of this movement, of heterogeneous membership, that is expressed at major events which regularly bring together self-styled altermondialists at a European and planetary level. It is noticeable, in fact, that the dividing lines are not always that sharply defined. To take the case of Oxfam, one of it components, Oxfam Solidarity (Jennar 2004), has taken a radical position from which Oxfam International has very clearly distanced itself.

The fact remains that even big NGOs that participate fully in the system of international relations conduct violently anti-establishment campaigns at the same time. They have been accused of playing a double game, by simultaneously cultivating protest and negotiation. But is not such duality an integral part of this kind of organization? And, above all, are we not seeing a mode of governance taking shape that will tend to integrate opponents into a broader dynamic? This is the argument of Ulrich Beck, according to whom the "cosmopolitical era" we have entered is characterized by "a system of enemies without enemies" integrating governments and protestors. We are finally seeing them coming together on topics where they once seemed opposed on all 
points, such as the canceling of the debt of the poorest countries. Similarly, many leaders recognize the value of the Tobin tax.

Are not NGOs therefore "the conscience of governments" (Beck 2005)? Whatever the case, the links being forged between companies and non-governmental organizations are evidence of this new order: Coca Cola is helping France's Secours Populaire association, the Carrefour supermarket chain is supporting the Fédération internationale des Droits de l'homme (the International Federation for Human Rights), Havas is contributing to the efforts of Care, and so on.

A more complex game is taking shape, where the partners of worldwide governments are no longer just states and international organizations that have emerged out of governmental wishes. Now, moral and economic "private authorities", NGOs and companies have joined in. It is a game in which the weapon of collective rallying, heavily covered in the media, has an important place, but where the practice of partnerships and negotiating is very real. It is relevant to note the way in which the one-on-one debate is unfolding around the virtually simultaneous "staging" of the Davos and Porto Alegre forums - the former bringing together the managing elite of the global economy and the latter created as a platform for the excluded and for victims of globalization. In 2005, Brazil's President Lula, founder of the country's Labor Party and one of altermondialism's symbolic figures, traveled to Davos after having spoken at Porto Alegre. He said the following: "Included in this approach is the task of discussing possible common areas between the World Social Forum in Porto Alegre and the World Economic Forum in Davos, which is taking place at the same time. It is not a matter of asking people to stop being who they are but of establishing links between communities united by an indivisible human destiny." (Lula da Silva 2005)

In this context, it is interesting to compare Beck's ideas with the analyses of Hardt and Negri (2000), since they are symptomatic of an approach that radically challenges the nation-state concept, in observing that an all-inclusive entity is being put in place which the former identifies as a "cosmopolitical regime" and the latter define under the heading of "empire". To counterbalance the virtually totalitarian character of this new political form, Hardt and Negri, faithful to the Marxist tradition, base their hopes on deep movements that will allow the multitude to establish itself, while Beck, in the tradition of 
Habermas, banks on a project that will ensure the merging of democracy and the rights of man. Curiously, both works conclude by referring to religion. Beck talks of cosmopolitanism as a "terrestrial religion" or a "secularized divine order", while the authors of Empire evoke the image of Saint Francis of Assisi. Similarly, they refer to the concept of love, peculiar to Christianity and Judaism, or "Divine love for humanism and human love for God" and decide on the need to "rediscover the material and political meaning of love as a force opposed to death" (2004 397). Such religious references, in theoretical constructions that are meant, above all, to be rational and analytical, seem to me symptomatic. Perhaps we should place them in a context marked by the difficulty of comprehending the power question. It is as though we were seeing a sort of evasion at the heart of critical thought, in the face of developments that seem constantly to propel it towards a future that its own categories allow it to clarify only imperfectly.

It may, on the other hand, be literally blinded by the obvious omnipresence of that power (the "power without society") that reproduces itself without necessarily laying itself open, so that those who rally against it find themselves having to fall back on incantation. This situation is particularly noticeable amongst the altermondialists - heirs to a rhetoric dominated by the concepts of society and state, who themselves admit the trouble they have redefining a strategy together. We will hardly be surprised, then, at the success of forums - spaces where the word reigns supreme, where endless discussions go on concerning the changes in the world, where people come to recharge their batteries, express themselves, weigh up the evils of the present and peer into a black future.

Are these true places of debate? Do people really gather here to produce decisions? I was going to say, "certainly not!", given that it seems to me that forums - and even more so their "online" equivalents - are above all contexts for the trading of words. This great word market enters into a symmetrical relationship with the distant and mysterious powers of "the markets". These realms, which lie behind the decisions governing our daily lives, produce primarily figures - net results, the effect of which will be seen in the creation or elimination of jobs, and in relocations. But the great word market finds it harder to gear itself into action: from it come stances and suggestions and a vague force which in contrast to the preceding period, is no longer oriented towards establishing a new world with a brighter future. In this context, it is not surprising that NGOs should 
want to get out while the going is good - from a structurally double game. They are as much at ease in the domain of words as they are in the realism of action, where they have established a constructive partnership between the finance and the economy of survival.

We should not, however, seek to explain the rise in power of the NGO phenomenon as the end result of a successful combination of humanitarian ideology and a pragmatism that is ever on the alert in the noise and clamor of the world. Similarly, the place occupied today by transnational institutions such as the WTO, the UN and the IMF is not merely due to their functionality in the global system. In fact, we are witnessing a reconfiguration of the political domain which does not content itself with the development of governance exclusively centered on territoriality, any more than it implies the extinction of the nation-state - a world without sovereignty. This is why theories traditionally based on the dialectic between power and society focus on the change of scale (where is power situated and which is the relevant political space?, etc.), in search of an impossible return to order and an unattainable harmony where the forces of society recover control of this increasingly distant and mysterious power, which would make it possible to remedy imbalances and inequalities. These theoretical and political elaborations have in common that they all exist within a logic of harmonious living together (convivance), while the practices we are dealing with are unfolding in context of survival (survivance). To use Michel Foucault's distinction, these practices come within the "pastoral" dimension of pastoral power and apply less to "civil subjects" than to "living individuals".

If one can talk of global governmentality in reference to this constellation of transnational institutions and organizations, it is not in the sense of an inclusive reordering, like that of one power overlaying existing powers. This vision of things comes under the issue of harmonious living together (convivance). Its final realization is "empire", a construction that falls within the same paradigm as the "state" of the philosophers - a form intended to organize the communal life of subject citizens. Yet, in societies where threat is an integral dimension of the present, questions of life and survival now appear much more fundamental - so ideas of balance and order, justice and law only have sense in the context of a risk/precaution-oriented viewpoint. 
It is no accident that the theme of sustainability is now so profoundly tied in with theories to do with inequalities and the relationship between power and society. When, therefore, citing the frightening imbalance between the rich and poor countries, the Brazilian president writes, "Solidarity with life must always overcome the mechanisms of death. Debts must be honored, but payment must not mean the euthanasia of the debtor. The holders of the surplus of financial wealth must consider the social deficit afflicting three-quarters of humanity", who is a debtor towards whom? Is it the poor one, who has been given a loan by the rich one but is getting daily into deeper debt? Is it the rich one, laying down the law to the world and profiting from inequalities? In raising once more the issue of social deficit, Brazil's leader is rubbing salt into the wound. While advocating a vital rebalancing and a reorganization of society, he is referring explicitly to life ("solidarity with life") and death (the need to overcome the "mechanisms of death"). These terms, far from being innocuous, deserve our full attention. They refer back directly to the issue of harmonious living together (convivance), in the name of which he considers that it is impossible to stick to the traditional divides - by excluding himself from the Davos forum because he is one of the major figures of Porto Alegre. Symbolically, the terms of the theory and the stance that results from it thrusts us into multidimensional issues - some will say into a problematic dualism - since he explicitly admits that accepting the requirement of "solidarity with life" involves greater presence in the new centers of transnational politics.

The separation of living individuals and civil subjects highlighted by Foucault, has, in our own historical context, led to the emergence of the issue of harmonious living together (convivance) and its expression in a political space which, while it ties in with the traditional domain of "international relations", actually goes far beyond it. This space has become denser by, in some sense, internalizing anthropological anxiety in the face of an assortment of threats, ranging from terrorism to the planet's ecological vulnerability while the nation-state form was unable to give a satisfactory answer to the question of the rights of man. Dialoguing with Habermas on the subject of terrorism and the events of September 11, Jacques Derrida compared the way death and destruction arise from within a society to an auto-immune process. Evil neither arises from the exterior nor is the fruit of contamination - life itself works to destroy its own protections. 
For this philosopher, what characterizes the retrospective perception of the events of September 11 is that they are experienced not just as an aggression (certainly violent, but in the past) but also as an opening onto an almost equally threatening future. "We are talking about a trauma, and thus an event, whose temporality proceeds neither from the now that is present nor from the present that is past but from an im-presentable to come." (2004:147) What is setting in is a fear of the worst - of bacteriological or even nuclear aggression. "Traumatism is produced by the future, by the to come, by the threat of worse to come, rather than by aggression that is "over and done with"' (2004:148). In this context, Derrida underlines the role the international institutions could have, "imperfect though they may be", and brings up the outlook of "a new figure, not necessarily in the form of the state, of universal sovereignty". Concerning what he himself describes as "utopian", the philosopher wonders if he shouldn't describe this "ultimate form of sovereignty that would reconcile absolute justice with absolute law" as "Coming God", and invoke, in this connection, "messianicity without messianism" (2004:170-171).

When Derrida links the idea of an international juridico-political space to a "to-come" (a future) whose realization amounts to the "possibility of this impossible thing", this is not a matter of verbal caution. I tend to see in it rather the desire to bring to light the extraordinary difficulty of not flattening the new dimension of "global politics" by sticking to a purely institutionalist vision. Global politics casts us into a system of anticipation and bears the hallmarks of lack of fulfillment. It cannot be contained in terms of power balances nor thought of as a superstate form. It is developing, to some extent, alongside the world of territorial sharing, without imposing itself on states and on traditional systems of sovereignty as an overshadowing power. Between the nation-state and global politics we find the same polarity as that which exists between the system of harmonious living together (convivance) and the system of survival (survivance). Today, global politics is, to a high degree, dependent on the strategies of nation-states. However, as the impact of initiatives dealing with the economy of survival show, it imposes its own system and puts under pressure those powers that control it only imperfectly.

One way of interpreting the way in which themes represented by the NGOs establish themselves is to conclude that global politics contaminates sovereignty. Global politics manifests in the big planetary events that excite the response of the media. These can be 
the occasion of confrontations, as in the case of the WTO conference in Seattle (1999), when demonstrators blockaded the town. Tragedy can also be involved, as during the G8 meeting in Genoa (2001), when confrontations with the police led to the fatal shooting of a young man.

In a completely different, but equally spectacular context, the huge concerts initiated by Bob Geldof and others shine a harsh light on the ills that afflict the world and the dangers that threaten it. Here, all who wish to can take part in the group emotion in situ, unless they prefer sharing in it before their television screen.

It is on very varied levels, then, that we are seeing a group power take shape, made of tensions and even confrontations and rallying protagonists from widely diverse strata. These rallyings have a highly variable content, since they can express the violence of dissensus just as readily as they can give rise to the sort of humanitarian unanimity we saw in the days following the Asian tidal wave. In fact, we are dealing with performances, whose effect is to bring to the forefront of the political agenda issues which hitherto came under the umbrella of ethics and religion. Natural disasters and humanitarian catastrophes give rise to what, once upon a time, was known as l'horreur sacrée (fear of divine retribution).

Rather than worldwide disillusionment, which some see as synonymous with modernity, perhaps the sacred is making a comeback and manifesting in charitable behavior and the predisposition to give? In this case, we should not see the magnitude of the charitable reaction as an epiphenomenon - a reaction entirely explicable by contextual factors - but take seriously the way in which the issue of survival is now establishing itself as a challenge of citizenship, globally as well as locally. That anthropological anxiety focused on survival should lastingly reshape not only our perception of the world but also our modes of political action, by changing our priorities and generating new debates and totally new initiatives, provides food for thought to those currently wondering about the future of the relationship between the individual and the group and, beyond that, the political and the sacred.

This concrete expression of global politics on the emotional level sometimes seems like a kitsch stage performance, strangely hybrid thanks to the simultaneous presence of characters from different "scenes". The Davos forum featured stars of screen and show 
business, from Sharon Stone to Peter Gabriel, from Lionel Richie to Richard Gere. Youssou N'Dour wrote a song on malaria. "We thought we'd been great at getting big names in business, politics and media, but not great at celebrities. It's a goldmine," said Claudia Gonzalez, one of the forum's organizers. They follow modestly in the wake of Bono, the pioneer of global militantism. What is certain is that we are communing in a ritual that trains the spotlights on the misery of the Third World and the ever-renewed struggle to ensure conditions favorable to sustainable development. What makes this kind of ritual so powerful is the plurality of the protagonists and the diversity of their sympathies, and the fact that the charisma lies not so much with the political power as with the artists. Global politics draws it efficacy from its capacity to evoke the outlook of survival (survivance) in very varied ways. Through performances ranging from these charitable displays to great mass demonstrations, which also spark off the confrontation between the voices of the powerful and the poor, global politics highlights the world's precariousness and suggests possible initiatives and ways out by which we might remedy the catastrophic effects generated by the identical reproduction of our societies.

It is not by chance that the sacred dimension is present, to the degree that we can compare the rallyings unleashed by the great catastrophes to veritable expiatory rituals. In encompassing uncertainty about the "to-come", global politics does not only call upon science and expertise - although these play an increasing role in organizations dealing with sustainable development and ways of defeating poverty. Hope and belief are very present in the emotions global politics give rise to. In associating the idea of a Coming God with a democratic future in which national state sovereignty is overtaken, Derrida, in his way, echoes the contradictions produced by the globalized political space. In the issue of harmonious living together (convivance), however, the dissociation of the religious and the political finds its quintessence in the secular ideal of the separation between church and state (which claims to separate the world of belief and management of the city), in the perspective of survival (survivance), this type of division becomes problematic. The crossover between sacred and profane can be seen in both great media ceremonies and theories on globalization. As we have seen, adepts of the cosmopolitical or alter idea are quick to evoke paradise on earth or the figure of Saint Francis of Assisi. 
The complexity of global politics means we cannot just see it as a substitute for existing politics. Those who have tried to think through and promote the overtaking of the nation-state, using concepts or constitutional formulas, have so far got nowhere. Today, alongside the political places of sovereignty organized around the institutional division of executive and legislative, another space is emerging where the legitimacy of a decisionary monopoly becomes increasingly blurred. For anthropologists, this type of political place is distinguished by the absence of separation between "within" and "without". The technical nature of the material dealt with, however, tends to give rise to such separation. Similarly, during planetary conferences, enclosing the negotiators in a stage set of grand palaces and subjecting them to continual surveillance reinforces the feeling of a divide between the elite and the outside world. In Cancun, as in Seattle, however, it is no accident that we see pressure groups from the four corners of the world converging on the negotiating site. This massive presence is a major factor in modifying our spontaneous perception of a world where political and diplomatic initiative is the exclusive right of a minority that holds all power and knowledge. This aspect attracts insufficient attention from specialist observers, who focus more on the spectacle of the dispute and on its media figureheads.

Perhaps it is time to modify our vision of politics, obscured as it is by the search for a predominant and omnipotent political "place", while what is actually evolving is a set of systems that undermine the perception of sovereignty that has long been the foundation of western governmental practices. With global politics, the issue now on the agenda is that of a politics of survival - and this is being expressed in most varied ways in the public space. The fact that the problem of survival is now at the center of our ways of practicing and thinking about today's politics is a new factor, in this young century, the full implications of which are yet to become apparent. The fact that fear of the unknown can transform politics at the deepest level, that the sense of threat people feel should become a major torment in our societies, that the political ideal should shape parliamentary business (and not vice versa) by causing a rise in the power of transnational operations, that collective aspirations and even individual electoral behavior should be determined by the precautionary principle, are factors that should make us update our analytical grids and ways of acting. Odds are that the period now beginning will expand this approach to 
politics. Will the undercurrent end up by changing the rules of the game and changing the hierarchies currently found in the corridors of power? Or, conversely, might the governing powers adapt gently, making ample space for requirements they once considered marginal? It is too soon to claim we can answer these questions. What is certain, though, is that it will not be long before we see the full impact of the virtualities contained within the politics of survival.'

NOTE: An earlier version of this article was presented at Princeton University Department of Anthropology Seminar. Thanks to Carol Greenhouse, Joao Biehl, James Boon and John Borneman for their comments.

\section{REFERENCES CITED}

Appadurai, A. 1996. Modernity at Large. Cultural Dimensions of Globalization. Minneapolis, Minn.: University of Minnesota Press.

Arendt, H. 1958. The Human Condition. Chicago: University of Chicago Press.

Badie, B. 1999. Un Monde sans souveraineté. Paris: Fayard.

Beck, U. 2005. Politics in the Global Age : a New Global Political Economy. Cambridge UK; Malden, MA: Polity.

Castel, R. 2003. L'Insécurité sociale. Paris: Seuil.

Canetti, E. 1962. Crowds and Power. New York: Viking Press>

Derrida, J. 2004. Le "concept 》 du 11 septembre, Dialogues à New York (octobredécembre 2001) avec G. Borradori. Paris: Galilée.

Foucault, M. 2001. Dits et écrits II, 1976-1988. Paris: Gallimard,

Foucault, M. 1997. «Il faut défendre la société ». Cours au Collège de France, 1976. Paris: Gallimard, Seuil.

Agulhon, M. 1989. Marianne au pouvoir. Paris: Flammarion.

Jennar, R.M. 2004. Europe, la trahison des élites. Paris : Fayard,.

Beck, U. 2005. Power in the Global Age: a New Global Political Economy. Cambridge, UK ; Malden, MA : Polity.

Lula da Silva, L. I. 2005. Entre Davos et Porto Alegre, des champs communs possibles. Le Monde, 27/01/2005.

Negri, A. and M. Hardt, M. 2000. Empire, Cambridge, Mass.: Harvard University Press. 
Negri, A. and Hardt, M 2004. Multitudes. War and Democracy in the Age of Empire. New York: The Penguin Press.

Robertson, R. 1992 Globalization, Social Theory and Social Culture. London: Sage Publications.

Rosenau, J. and Czempiel, E.O. 1992. Governance without Government: Order and Change in World Politics. Cambridge: Cambridge University Press.

Sassen, S. 1998. Globalization and Its Discontents, New York:The New Press.

Strange, S. 1996.The Retreat of the State. The Diffusion of Power in World Economy, Cambridge: Cambridge University Press. 


\begin{abstract}
When trying to understand the political displacement, the emergence of new transnational powers and of new transnational forms of resistance, the analysis in terms of institutions and players may seem insufficiently relevant. The reorganization of traditional powers and the increasing power of the transnational on a planetary scale is only the top of the iceberg. We can observe that is a set of systems is actually evolving that undermine the perception of sovereignty that has long been the foundation of western governmental practices. What has to be clarified is the very meaning we give today to politics, and our perception of the political dimension, which is in the process of radically changing. In Analyzing global politics, I suggest that the main issue on the agenda is that of a politics of survival - and this is being expressed in most varied ways in the public space, as in the NGO's mobilisations and in the transnational forums.
\end{abstract}

\title{
KEY WORDS
}

Politics, Power, Globalization, Survival, NGOs 